\title{
Contents, Volume 1 (1990)
}

Akar, H.: see Tomminen, J. \& Akar, H. ....................... 171

Andersen, T.: see Søli, G. E. E. \& Andersen, T. .......... 155

Bilewicz-Pawinska, T. \& Varis, A. L.: Response of parasitoids of the genus Peristenus Förster (Hymenoptera, Braconidae) to temperature changes during the dia-

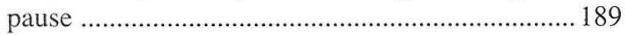

Coscarón, M. C.: A phenetic study of the genus Rasahus Amyot \& Serville (Heteroptera, Reduviidae) ....... 131

Disney, R. H. L.: Two new species and a revised key to Rhynchomicropteron (Diptera: Phoridae) ................21

Disney, R. H. L.: A striking new species of Megaselia (Diptera, Phoridae) from Sulawesi, with re-evaluation of related genera.

. .25

Disney, R. H. L.: A key to Diplonevra males of the Australasian and Oriental Regions, including two new species (Diptera, Phoridae)

33

Erzinclioglu, Y.Z.: The larvae of two closely-related blowfly species of the genus Chrysomya (Diptera, Calliphoridae) 151

Fürsch, H.: Die afrikanischen Arten der Scymnus frontalisGruppe (Coleoptera, Coccinellidae) ....................... 163

Gordeeva, E. W. \& Niemi, R.: Medioppia centrodentata sp. n. (Acarina, Oribatei, Oppiidae) from Bulgaria .... 129

Haila, Y. : see Niemelä, J., Halme, H. \& Haila, Y. .....233

Halme, H.: see Niemelä, J., Halme, H. \& Haila, Y. ...233

Heikinheimo, O.: Aphid species and morphs new to the fauna of Finland (Homoptera, Aphididae, Macrosiphini).

65

Heikinheimo, O.: Nasonovia (Kakimia) saxifragae (Doncaster \& Stroyan) (Homoptera, Aphidoidea) found in northern Fennoscandia

Heliövaara, K., Väisänen, R., Kemppi, E. \& Lodenius, M.: Heavy metal concentrations in males and females of three pine diprionids (Hymenoptera) 175

Heliövaara, K., Väisänen, R. \& Mannerkoski, I.: Melanophila formaneki (Jakobson) (Coleoptera, Buprestidae) new to Finland

221

Horstmann, K.: Typenrevision der von Hellén beschriebenen Cryptinae (Hymenoptera, Ichneumonidae) .......... 181

Index to genera and species, Volume 1 (1990) .............239

Itämies, J., Kuusela, K. \& Räinä, P.: Records of Atherix ibis in Finland (Diptera, Athericidae) .......................... 113

Itämies, J.: see Laine, A., Orell, M. \& Itämies, J. ........ 193

Jansson, A.: Entomologica Fennica - a new journal replacing earlier international Finnish entomological journals

Jansson, A.: Tetropium gabrieli Weise (Coleoptera, Cerambycidae), an interesting import species new to Finland
Karppinen, E. \& Poltavskaja, M. P.: Some new oribatids (Acarina, Oribatei) from the Rostov-Don region, Soviet Union. 103

Kemppi, E.: see Heliövaara, K., Väisänen, R., Kemppi, E. \& Lodenius, $\mathrm{M}$. 175

Kuusela, K.: see Itämies, J., Kuusela, K. \& Räinä, P. . 113

Laine, A., Orell, M. \& Itämies, J.: Invertebrate fauna on Norwegian spruce (Picea abies) branches in northern Finland .... 193

Lammes, T. \& Rinne, V.: Maps of the provincial distribution of Finnish Heteroptera ....................................209

Linnavuori, R. E.: Two new Heteroptera species, Orthotylus leokhares sp. n. (Miridae) and Rhyparochromus (Raglius) tisifone sp. n. (Lygaeidae) from Israel and Iraq.

Linnavuori, R. E.: Revision of the Atomophora complex (Heteroptera, Miridae) of the Eremian subregion...45

Linnavuori, R. E.: Taxonomy of the genus Compsonannus Reuter (Heteroptera, Miridae) of the Eremian subregion. 123

Lodenius, M.: see Heliövaara, K., Väisänen, R., Kemppi, E. $\&$ Lodenius, $\mathrm{M}$. 175

Mannerkoski, I.: see Heliövaara, K., Väisänen, R. \& Mannerkoski, I. 221

Nartshuk, E. P. : Chloropid flies (Diptera, Chloropidae) of Cyprus 227

Niemelä, J.: Habitat distribution of carabid beetles in Tierra del Fuego, South America ...................................... 3

Niemelä, J., Halme, H. \& Haila, Y.: Balancing sampling effort in pitfall trapping of carabid beetles ............ 233

Niemi, R.: see Gordeeva, E. W. \& Niemi, R. .............. 129

Orell, M.: see Laine, A., Orell, M. \& Itämies, J.: Invertebrate fauna on Norwegian spruce (Picea abies) branches in northern Finland

Poltavskaja, M. P.: see Karppinen, E. \& Poltavskaja, M. P.

Pont, A. C.: Notes on Finnish Sepsidae and Muscidae

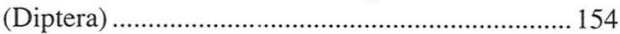

Pototski, A.: Five species of fleas (Siphonaptera) new to the Estonian fauna 180

Raatikainen, M. \& Vasarainen, A.: Biology of Metadelphax propinqua (Fieber) (Homoptera, Delphacidae) .... 145

Räinä, P.: see Itämies, J., Kuusela, K. \& Räinä, P. ..... 113

Rassi, P.: see Väisänen, R. \& Rassi, P. ......................... 107

Rinne, V.: see Lammes, T. \& Rinne, V....................... 209

Saaristo, M. I.: New provincial records for twelve ant species (Hymenoptera, Formicidae) from Finland 191

Silfverberg, H.: The nomenclaturally correct names of some family-groups in Coleoptera 
Silfverberg, H.: Records of Galerucinae (Coleoptera, Chrysomelidae) from the Indian subcontinent. Part 1

201

Šulcs, I.: Bucculatrix latviaella sp. n. aus Lettland (Lepidoptera, Bucculatricidae) ... 41

Søli, G. E. E. \& Andersen, T.: Polymorphism in Noctua pronuba (Lepidoptera, Noctuidae) in southern Norway .155

Tomminen, J. \& Akar, H.: Infestation of four coleopteran species by the pine wood nematode Bursaphelenchus xylophilus (Nematoda, Aphelenchoididae) living in wood chips 171

Väisänen, R. \& Rassi, P.: Abundance and distribution of Geotrupes stercorarius in Finland (Coleoptera, Scarabaeidae) 107

Väisänen, R.: see Heliövaara, K., Väisänen, R., Kemppi, E. \& Lodenius, $\mathrm{M}$

175

Väisänen, R.: see Heliövaara. K., Väisänen, R. \& Mannerkoski, I. .. 221

Varis, A. L.: see Bilewicz-Pawinska, T. \& Varis, A. L. ... 189

Vasarainen, A.: see Raatikainen, M. \& Vasarainen, A. ....

\section{Literature reviews}

Barbosa, P. \& Wagner, M. R.: Introduction to forest and shade tree insects. (U. Carlberg) 200

Bernays, E. A. (ed.): Insect-plant interactions. I. (U. Carlberg) 208

Campbell, I. C. (ed.): Mayflies and stoneflies: Life histories and biology. (H. Silfverberg) .

Emmet, A. M. \& Heath, J. (eds.): The moths and butterflies of Great Britain and Ireland. 7(1): Hesperiidae Nymphalidae. The Butterflies. (H. Silfverberg) ... 122

Ridgway, R. L., Silverstein, R. M. \& Inscoe, M. N.: Behavior-modifying chemicals for insect management. Applications of pheromones and other attractants. ( $\mathrm{T}$. Tuovinen). 150

Soós, A. \& Papp, L. (eds): Catalogue of Palearctic Diptera. 6. Therevidae - Empididae. (W. Hackman) 32 